\title{
RELATION OF WHEAT SPECIES AND GENOMES IN AMINO-ACID COMPOSITION
}

\author{
Pal Pepo \\ University of Debrecen, Faculty of Agricultural, Food Sciences and Environmental \\ Management, Institute of Crop Sciences, Group of Genetic Sciences, \\ Debrecen 4032 Böszörmenyi St. 138. \\ pepopal@agr.unideb.hu
}

\begin{abstract}
As regards wheat varieties constituting a natural ploid series the issue of analysing diploid, tetraploid and hexaploid species is topical since ancient varieties can play significant roles in contemporary agriculture as well. Seventeen winter wheat varieties, out of which 2 diploid varieties carried genome A, 9 diploidic types had genomes $\mathrm{AB}$, two varieties had genomes $\mathrm{AG}$ and four varieties were hexaploid ones with genomes ABD, were analysed from the point of view of their amino acid compositions. The amino acid contents of Asp, Thr, Ser, Glu, Gly, Ala, Cys, Val, Met, Ile, Leu, Tyr, Phe, His, Lys, Arg, Pro (a total of 17) were determined in the varieties listed above.

It has been found that the amino acid contents of the grains genotype AA Triticum boeticum and T. monococcum exceeded the amino acid content of $T$. aestivum in respect of all the amino acids analysed in this experiment, with Glu being the only exception. In comparison with the aestivum wheat, essential amino acid contents showed a similarly favourable picture in the diploidic varieties mentioned. As regards type $A B$ tetraploid varieties excesses of $13-16 \%$, in comparison to the aestivum wheat, were found in essential amino acid contents. The amounts of non-essential amino acids in all the winter wheat varieties showed decreases irrespective of the ploid level.

What concerns the total amino acid content, all the winter wheat varieties with the exception of $T$. monococcum (A), T. dicoccoides (AB) and T. dicoccum (AB) contained less amino acid than the aestivum wheat. All the monocarbonic acid and aromatic as well as heterocyclic amino acid contents of the wildly growing Triticum boeticum (A) and the grown Triticum monococcum (A) (with polaric, apolaric R groups, diamino radicles) exceeded the same contents of T. aestivum. The value of the monoamino-dicarbonic acid, however, was lower in our experiment.
\end{abstract}

Keywords: wheat, different genomes, amino acids

\section{INTRODUCTION}

The issue of analysing diploid, tetraploid and hexaploid wheats is topical since ancient varieties can play significant roles in contemporary agriculture. Some can be gene sources and valuable crops (VAllegA, 1979; Multani ET AL., 1992; D'EgIDIO ET AL., 1993). The domestication began over ten thousand years ago with ,einkorn” (Triticum monococcum L.) (HEUN ET AL., 1997) while the modern hexaploid hard wheat for bread making emerged eight thousand years ago. In addition to wheat varieties of the aestivum type, durum wheat (T. durum Desf.) (contains genomes $\mathrm{A}$ and $\mathrm{B}, 2 \mathrm{n}=28$ ) is produced on the remaining approximately $5 \%$ of the wheat production area. Recently, primarily in the hilly regions of Europe the production of the spelta ( $T$. spelta L.) wheat variety, which contains hexaploid genomes $(\mathrm{A}, \mathrm{B}$ and $\mathrm{D}$ genomes, $2 \mathrm{n}=42)$ has come to play a major role and is used in organic farming due to its smaller nitrogen requirement (VASIL AND VASIL, 1999). Einkorn (genome $A$ and $2 n=14$ ) is only grown occasionally for aminal nutrition. BARABÁS (1987) and RAGASITS (1998) deal with the history and taxonomy of wheat in detail in their books. The einkorn or diploid wheat is the earliest grown bread variety in production and one, which is supposed to have been the donor for genome „A” of the hexaploid (Triticum aestivum L.) and tetraploid (Triticum durum L.) varieties (KERBY AND KUSPIRA, 1988). 
Today the ancient varieties are only grown in marginal areas of former Yugoslavia, Turkey and Italy. Protein contents of the hexaploid and durum wheat varieties are high in Glu but low in Lys and Thr, which are especially important for human diets (WRIGLEY AND BIETZ, 1987). ACQUISTUCCI ET AL. (1995) compared 15 T. monococcum strains, two modern hexaploid and two durum wheat varieties as regards their protein contents and amino acid compositions. In the case of the einkorn strains there was positive correlation found between Glu and Pro values and protein contents while the same relations exhibited negative correlations as regards Thr, Ile, Leu, Asp, Ser, Gly and Ala. VALlEGA (1995) stated that protein contents of grains ranged between $14-25 \%$ when analysing $T$. monococcum strains but no types high in Lys concentrations could be selected during tests. When analysing the amino acid compositions of 44 spring wheat varieties ANJUM ET AL. (2005) found significant differences in certain genotypes. In the varieties analysed, they found considerable variability in Lys, Leu, Ile, Thr, Val, Met, His, Arg, Ala, Asp, Glu, Gly, Pro, Ser and Tyr contents. When analysing the protein and amino acid contents of wheat varieties, BOILA ET AL. (1996) found significant differences in protein concentrations, which findings were similar to those in certain amino acids. Amino acid content of wheat is also influenced by several other factors: amount of nitrogen, damage by pests (ZAHEDI ET AL. 2004, JOOD ET AL. 1995). When analysing grain crops MATUZ ET AL. (2000) found the highest protein contents (18.2-20.9\%) in varieties T. monococcum, $T$. spelta and an old Hungarian bread wheat variety Bánkúti 1201. Similarly, the highest total amino acid contents were found in these varieties. When analysing the total protein amount ABDEL-AAL AND HUCI (2002) found in the so-called ancient varieties that the amount of total protein per total milled volume was varied in the case of einkorn varieties and the highest values $(17.7 \%)$ were provided by the hard-grained spelta variety. When analysing biochemical parameters of stored proteins IVANOV ET AL. (1998) found similar amino acid compositions in the wheat variesties and strains of the aestivum type and the essential amino acid level also showed a negative correlation with the total protein amount.

The quality of plant and thus that of wheat is shaped by the genotype, the environmental conditions and their interactions. The contemporary rich Hungarian choice of varieties offered gives producers an opportunity to use an appropriate genetic base best suited the location of production and the type of management chosen (SIPOS ET AL., 2003; GYÖRI, 2006; SIPOS ET AL., 2006; TÓTH ET AL., 2006).

\section{MATERIAL AND METHOD}

The wheat varieties analysed in this experiment come from the gene-bank collection of the Agrobotanikai Kutató Intézet (Institute of Agrobotany) in Tápiószele Hungary. A total of 17 varieties with different levels of diploid, tetraploid and hexaploid chromosomes were analysed, their genome compositions were the following:

Genome „A” was found in: Triticum boeticum L., Triticum monococcum L. ssp. monococcum (SLAGEREN, 1994).

Genomes „A” and „G” were found in: Triticum timopheevii Zhuk. ssp. timopheevii, Triticum petropavlovskyi (DOROFEEV ET AL. 1979).

Genomes „A” and „B” were found in: Triticum turgidum L. ssp. dicoccoides, Triticum turgidum L. ssp. dicoccum, Triticum turgidum L. ssp. durum (Desf.), Triticum turgidum L., Triticum turgidum L. ssp. turanicum, Triticum turgidum L. ssp. carthlicum, Triticum turgidum L. ssp. polonicum, Triticum ispahanicum L., Triticum karamyschevii L. 
Genomes „A”, „B” and „D” were found in: Triticum aestivum L. ssp. spelta, Triticum aestivum L. ssp. compactum, Triticum aestivum L. ssp. macha, Triticum aestivum L.

The samples were analysed in the Equipment Centre of the Centre for Agricultural Sciences of the University of Debrecen according to the appropriate MSZ, MSZ-ISI standards and by using the AACC method and also by making use of our own testing methods. The flour was milled from the wheat according to Hungarian Standard No. MSZ 6367/9: 1989 with a LABOR MIM AQC-109 laboratory mill. Different types of amino acids except for Asn, Gln, Trp were determined with Biotronik LC 3000 Analyser (liquid chromatograph with cation exchange column) after acidic (HCI) hydrolysis (STEIN AND MOORE, 1963). Asparagine (Asn), glutamine (Gln) and triptophane (Trp) were not studied. Asn and Gln are neutral amino acids, so cation exchange column is not suitable for their determination, while Trp totally disintegrates during acidic hydrolysis, so HPLC is the right method for its examination.

In order to mark the individual amino acids analysed in this experiment, the following generally accepted abbreviations were used: Asp (aspartic acid), Thr (threonine), Ser (serine), Glu (glutamic acid), Gly (glycine), Ala (alanine), Cys (cysteine), Val (valine), Met (methionine), Ile (isoleucine), Leu (leucine), Tyr ( tyrosine), Phe (phenylalanine), His (histidine), Lys (lysine), Arg ( arginine), Pro (proline).

SPSS 12.0 software was used in processing the data statistically. The diagrams showing average values and variance were made by using Microsoft Excel 2003 software.

\section{RESULTS AND DISCUSSION}

We investigated the amounts of essential and non-essential amino acids in winter wheat grains, while Figure 1 shows the distribution of these types of amino acids in varieties with different genomes. According to the classification by HíDVÉGI AND BÉKÉS (1983) amino acids that living organisms cannot produce or can only produce in small quantities in relation to the demands are called essential amino acids and these have to be supplemented through a diet. They are: Arg, Cys, Tyr, His, Lys, Phe, Trp, Ile, Leu, Met, Thr, Val. Nonessential amino acids are classified as follows: Ala, Asn, Asp, Glu, Gln, Gly, Pro and Ser. The amino acids analysed by the Equipment Centre were classified into essential and nonessential amino acids according to the lists above. The data reveal that the essential amino acid contents of genome A, T. boeticum and T. monococcum exceeded the relevant aestivum values by $67.3 \%$ and $45.5 \%$, respectively. As regards type $\mathrm{AB}$ wheat varieties excess amino acid amounts of $14.5-27.3 \%$ were found in T. petropavlovskyi, turgidum, carthlicum, dicoccum, dicoccoides in comparison with the aestivum wheat variety. In the case of wheat varieties with an ABD genome structure the amino acid contents were nearly the same.

As regards the non-essential amino acid contents we can see that it was only the $T$. boeticum (A) that reached an excess amount by $9 \%$ in comparison with the aestivum wheat. Irrespective of the level of ploidity compared to the total one in all the winter wheat varieties and the extent of this decrease was $0-42 \%$. As regards the total amino acid contents $T$. boeticum (A) exceeded the aestivum wheat variety by $26.2 \%$. On the other hand, the total amino acid contents of all the winter wheat varieties analysed were below (by $0-32.1 \%$ ) of that of the aestivum wheat, the only exceptions being T. monococcum (A), T. dicoccoides $(\mathrm{AB})$ and $T$. dicoccum $(\mathrm{AB})$. 


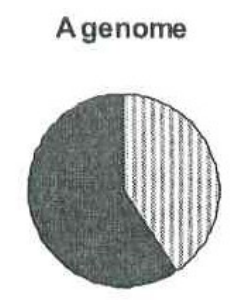

$A B$ genome

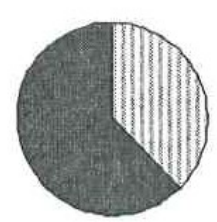

AG genome

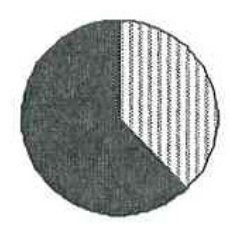

ABD genome

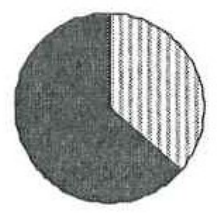

口essential amino

acids

배 non-essentia

amino acids

Figure 1. Essential and non-essential amino acid compositions of winter wheat varieties with different genomes

Essential amino acids: Arg, Cys, Tyr, His, Lys, Phe, Ile, Leu, Met, Thr, Val

Non-essential amino acids: Ala, Asp, Glu, Gly, Pro, Ser

We also elaborated the amounts of amino acids in wheat varieties according to their chemical structures. Figure 2 shows the distribution of these types of amino acids in varieties with different genomes. The following groups were set up:

- monoamino-monocarbonic acids with an apolaric R group: Gly, Lys, Ala, Val, Leu, Ile, Met

- monoamino-monocarbonic acids with a polaric R group: Ser, Thr, Cys

- diamino-monocarbonic acids (basic amino acids): Lys, Arg

- monoamino-dicarbonic acids (acid amino acids) and their amides: Asp, Glu, Asn, Gln

- aromatic amino acids: Phe, Tyr

- heterocyclic amino acids: His, Pro
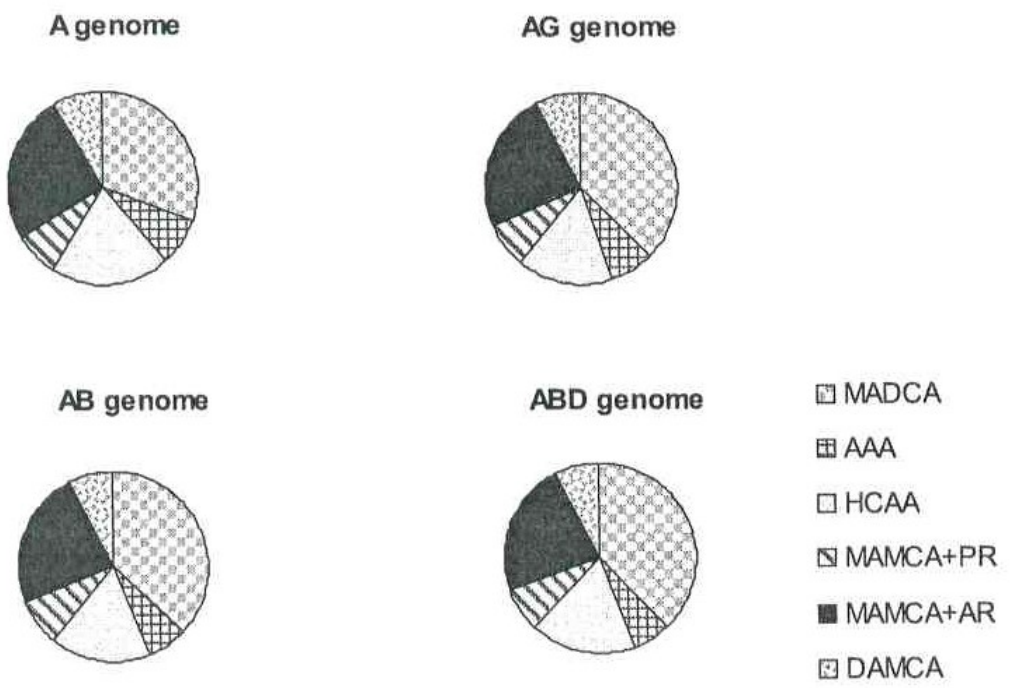

Figure 2. Amino acid compositions of winter wheat varieties according to chemical groups

MADCA: monoamino-dicarbonic acids, AAA: aromatic amino acids, HCAA: heterocyclic amino acids, MAMCA+PR: monoamino-monocarbonic acids with polaric R groups, MAMCA+AR: monoaminomonocarbonic acids with apolaric R groups, DAMCA: diamino-monocarbonic acids 
The data reveal that T. boeticum and monococcum, which have A genome have $27-28 \%$ more polaric group containing monoamino-monocarbonic acid than the aestivum type. With the exception of $T$. petropavlovskyi (AB) and $T$ turgidum (AB) the other wheat varieties had less of this amino acid than T. aestivum. The diploid T. monococcum and the variety $T$. boeticum, which contain monoamino-monocarbonic acid with an apolaric group exceeded this content of the aestivum wheat by $37 \%$ and $63 \%$, respectively. The apolaric monoamino-monocarbonic acid contents of all the other wheat varieties with the exception of winter wheat varieties T. petropavlovskyi (AB), T. dicoccoides (AB), T. turgidum (AB), T. carthlicum $(\mathrm{AB})$ and $T$. dicoccum $(\mathrm{AB})$, which have excesses of $10-20 \%$, were in the same region as the aestivum wheat.

As regards diamino-monocarbonic acids there was more of them in each variety than in $T$. eastivum and with respective values of $63 \%$ and $76 \%$ the diploidic $T$. boeticum and $T$. monococcum, which have genome A, stand out. Monoamino-dicarbonic acid contents were $10-55 \%$ smaller than that of T. aestivum.

The amounts of aromatic amino acids in T. boeticum (A) and T. monococcum (A) were 95\% and $47 \%$ higher, respectively, than in T. aestivum. The aromatic amino acid contents of the other winter wheat varieties analysed exceeded that of $T$. aestivum and it was the varieties $T$. dicoccum (AB), T. turgidum (AB) and T. petropavlovskyi (AB) with excesses of $22-32 \%$ that was outstanding. As regards heterocyclic amino acids the picture is rather varied but even in this respect T. monococcum (A) and T. boeticum (A) surpassed $T$. aestivum by $30 \%$ and $61 \%$, respectively. In the cases of $T$. petropavlovskyi $(-21 \%), T$. durum (-37\%) and T. karamyschevii (-46\%) significantly smaller values were obtained.

It also shows a picture of the relative proportions of the amino acids that belong to different chemical groups. As regards the winter wheat varieties analysed in this experiment the ratio of monoamino-monocarbonic acids with polaric $\mathrm{R}$ groups ranged between $6.56-9.40 \%$, that of monoamino-monocarbonic acids with apolaric $\mathrm{R}$ groups in relation to the total amino acid volume was $19.09-28.21 \%$ and diamino-monocarbonic acids had a share of $5.72-9.72 \%$. The ratio of monoamino-dicarbonic acids, representing the highest amount, which was $28.82-47.01 \%$ in relation tot he amino acids found in wheat grains, while the ratios of aromatic amino acids and heterocyclic amino acids ranged between $5.38-8.38 \%$ and $11.11-20.52 \%$, respectively. In relation to $\mathrm{T}$. aestivum the occurrence of monoamino-dicarbonic acids in comparison to the total amount of amino acids is smaller, while that of apolaric monoamino-monocarbonic acids in the case of aromatic and heterocyclic amino acids is higher. Out of the amino acids with different structures it was the monoamino-dicarbonic acids, which serve as susbstitutes for nitrogen and also play a decisive role in the synthesis of nitrogen containing components, showed the highest variance.

\section{REFERENCES}

ABDEl-AAL, E.S.M., HUCI, P. (2002): Amino acid composition and in vitro protein digestibility of selected ancient wheats and their end products. Journal of Food Composition and Analysis 15:737-747.

Acquistucci, R., D'Egidio, G.M., Vallega, V. (1995): Amino acid composition of selected strains of diploid wheat (Triticum monoccum L.). Cereal Chem. 72:213-216.

Anjum, F.M., Ahmad, I., Butt, M.S., Sheikh, M.A., RAShA, J. (2005): Amino acid composition of spring wheats and losses of Lys during chapatti baking. Journal of Food Composition and Analysis 18:523-532. 
BARABÁs, Z. (1987): A búzatermesztés kézkönyve. (Handbook of Wheat Production). Mezőgazdasági Kiadó, Budapest. 538 p.

Boila, R.J., Stothers, S.C., CAMPbell, L.D. (1996): The relationships between the concentrations of individual amino acids and protein in wheat and barley grain grown at selected locations throughout -Manitoba. Canadian Journal of Animal Science 76:163-169. D'EGIDIO, M.G., NARDI, S VALlEGA, V. (1993): Grain, flour and dough characteristics of selected strains of diploid wheat (Triticum monococcum L.). Cereal Chem. 70: 298-303.

Dorofeev, V.F., Filatenko, A.A., Migushova, E.F., Udaczin, R.A., JaKubziner, M.M. (1979): Wheat. Vol. 1. In: Dorofeev, V.F., Korovina, O.N. (eds): Flora of Cultivated Plants. Leningrad (St. Petersburg), Russia. Kolos (in Russian). 346 p.

GYőRI, Z. (2006): A búza sütőipari minősége I. (Baking quality of wheat I.) Magyar Mezőgazdaság 12-13.

Heun, M., Schafer-Pregl, R., Klawan, D., Castagna, R., Accerbi, H., Borghi, B., SALAMINI, F. (1997): Site of einkorn wheat domestication identified by DNA fingerprinting. Science 278: 1312-1314.

HIDVÉGI, M., BÉKÉS, F. (1983): Mathematical modelling of protein nutritional quality from amino acid composition. Proc. Int.Assoc. Cereal Chem. Symp.Amino Acid Compn. and Biol. Value of Cereal Proteins (eds. Lásztity, R., Hídvégi, M.), Budapest, Hungary, pp. 205-241.

IVANOV, P., Todorov, I., Stoeva, J., IVAnOVA, I. (1998): Storage proteins characterization of a group of new Bulgarian high breadmaking quality wheat lines. Cereal Research Communications 26: 447-454.

JoOD, S., PoOR, A.C., SINGH, R. (1995): Amino acid composition and chemical evaluation of protein quality of cereals as affected by insect infestation. Plant Foods for Human Nutrition 48: 159-167.

KERBY, K., KUSPIRA, J. (1988): The phylogeny of the polyploidy wheats Triticum aestivum L. (bread wheat) and Triticum turgidum L. (macaroni wheat). Genome 30: 722-737.

MatuZ, J., BARTóK, T., MÓrocz-SAlamon, K., BóNA, L. (2000): Structure and potential allergenic character of cereal proteins- I. Protein content and amino acid composition. Cereal Research Communications 28: 263-270.

Multani, D.S., Dhaliwal, H.S., Sharma, S.K., Gill, K.S. (1992): Inheritance of induced morphological mutants in Triticum monococcum L. Plant Breeding 109: 259-262.

Ragasits, I. (1998): Búzatermesztés. (Wheat production). Mezőgazda Kiadó, Budapest. $120 \mathrm{p}$.

SIPOS, P., GYŐRI, Z., MARS, É., PUY, K. (2003): Investigation the relationship between the protein content, wet Gluten content and sedimentation volume of winter wheat. II. AlphsAdria Scientific Workshop. Croatia, Trogir. Ed.: Gyuricza, Cs. pp. 169-173.

Sipos, P., TóTH, Á., MARS, E., GYÖRI, Z. (2006): Effect of weather conditions on the alveographic W value of winter wheat. Cereal Research Communications 34: 657-660.

Slageren, M.W. (1994): Wild wheats: A monograph of Aegilops L. and Amblyopyrum (Jaub. \&Spach) Eig (Poaceae). Wageningen Agriculture University Papers 7:513.

SteIN, W.H., MoORE, M. (1963): Chromatographic determination of amino acids by the use of automatic recording equipment. In: Colowick, S.P., Kaplan, N.O. (eds): Methods in Enzymology. Academic Press, New York.

Tóth, Á., Sipos, P., Borbély, M., URI, Cs., Elek, Á., MARs, É., GYőRI, Z. (2006): Conections between glutenin proteins and rheological properties of winter wheat. Cereal Research Communications 34: 693-696.

VAllegA, V. (1979): Field performance of varieties of Triticum monococcum, T. durum and Hordeum vulgare grown at two locations. Genet. Agr. 33: 363-370. 
VALLEGA, V. (1995): Triticum monococcum: bread baking quality, amino acid composition and toxicity in coeliac disease. Annual Wheat Newsletter $41 \mathrm{p}$.

VASIL, I.K., VASIL, V. (1999): Transgenic cereals: Triticum aestivum L. (wheat). In: Vasil, I.K. (ed.), Molecular Improvement of Cereal Crops. Kluwer Academic Publishers, Dordrecht. The Netherlands, pp. 137-147.

Wrigley, C.W., Bietz, J.A. (1987): Proteins and amino acids. In: Pomeranz, Y. (ed.), Wheat Chemistry and Technology. Am. Assoc. Cereal Chem. St. Paul, Mn.

ZAHEDI, M., MCDONALD, G., JENNER, C.F. (2004): Nitrogen supply to the grain modifies the effects of temperature on starch and protein accumulation during grain filling in wheat. Australian Journal of Agricultural Research 55: 551-564. 